\title{
Co-creation and the development of SME designer fashion enterprises
}

\author{
Abstract \\ Purpose - The purpose of this paper is to examine the co-creation of SME designer fashion \\ brands during internationalisation.
}

Design/methodology/approach - As an exploratory study, this research utilises grounded theory methodology and incorporates the use of 38 semi-structured in-depth interviews with designer fashion enterprises and their support network of sales and PR agencies.

Findings - Co-creation was identified as an important element for the successful integration of the entrepreneurial designer fashion enterprise into the global fashion industry network. Within relationship marketing, the concept of co-creation emphasises consumer experience, influence and power in the development of brand value. However current understanding of co-creation inadequately explains the development of the entrepreneurial designer fashion brand, requiring examination of the concept using grounded theory. The findings of this research highlight how these small and medium enterprises react and respond to the interpretation of their brand identity through the co-creation process as they seek to introduce and grow their firms within the global fashion marketplace.

Originality/value - This paper identifies the influence of industry stakeholders on the process of fashion brand co-creation. Additionally, by identifying the process by which the entrepreneurial designer fashion enterprise navigates the introduction of their collections to the industry's network, and responds to interpretations of the firm's brand identity, this paper recognises the influence of the firm throughout the co-creation process.

Keywords: Co-creation, Brand development, SME, Fashion, Designer Fashion Enterprises, Brand Identity

Paper type: Research Paper

\section{Introduction}

Co-creation recognises the influence and power of consumers in the development of brands (Salzer-Mörling and Strannegård, 2004; Atwal and Williams, 2009; Choo et al., 2012). This has shifted the focus of marketing away from a product-focused approach to the identification, mirroring and servicing of consumer needs and desires. Brand value is now understood to be co-created through interaction that acts as a dialogue between the enterprise and its consumer (Tynan et al., 2010; Grönroos, 2011; Grönroos and Voima, 2011). Within marketing research, co-creation is a function of relationship marketing, introduced to facilitate and encourage the active participation of the consumer in the creation of brand value (Payne et al., 2008). This emphasis and focus on the consumer has shifted the understanding of exchange from tangible goods to intangibles and the use of servicedominant logic within marketing activities (Vargo and Lusch, 2004).

Service-dominant logic recognises that both consumer and firm are part of the value creating process (Grönroos, 2008, 2011; Grönroos and Voima, 2011) and advocates for the consumer's involvement at every stage of product development (Merz et al., 2009; Ind and Coates, 2013). However, this broad application of marketing recommendations presents challenges for firms within the fashion industry. For the entrepreneurial designer fashion enterprise (DFE), especially in the earliest stages of development, access to consumer information is in short supply. More significantly, the designer fashion brand is often defined by the underlying aesthetics of each collection carried over from season to season. It is the designer's vision, or unique point-of-view, that is the brand's point of differentiation within the fashion industry. These are two conflicting points about the development of brands within the fashion industry: that brand value is created through the identification and service of 
consumer needs, and that designer fashion brands are valued for the unique contribution of fashion designer(s) who create their vision, unveiling their collections during fashion week. Furthermore, the emphasis and focus of co-creation on consumer behaviour ignores the firm's reaction and response to co-created experiences throughout market interactions.

The aim of this paper is to explore the concept of co-creation of entrepreneurial DFEs during the course of internationalisation. It examines designer fashion brands based in London and New York who function within the small and medium enterprise (SME) sector. These enterprises operate at the pinnacle of the fashion industry, producing products within the designer ready-to-wear and contemporary price-points. While previous studies focus on the brand and product development of fashion retailers (Fernie et al., 1998; Guercini, 2001; Wigley and Moore, 2007; Goworek, 2010; McColl and Moore, 2011) or established luxury firms (Atwal and Williams, 2009; Fionda and Moore, 2009; Choo et al., 2012), this research explores brand development in entrepreneurial designer fashion enterprises.

Throughout data gathering and analysis the concept of co-creation emerged as an important element for the DFE, not only in connecting with their end consumers, but during the course of integration into the fashion industry. For the fashion industry in particular, research into co-creation ignores the dynamic network and system in which DFEs create their brands.

\section{Literature Review}

\section{Co-creation of Brand Value}

While brand development is increasingly identified as imperative for the long term economic sustainability of the firm, brand value is now understood to be built through marketing communication activities only to a limited degree (de Chernatony, 1999; Atwal and Williams, 2008). Shifting away from a product-centric view to relationship marketing, brands are now considered to be co-created (Prahalad and Ramaswamy, 2004). Co-creation recognises that consumers are not passive receivers of products and brands but are active participants in the creation of brand equity (Boyle, 2007; Choo et al., 2012) and their own value-in-use (Lusch and Vargo, 2006; Payne et al., 2008; Grönroos, 2008, 2011). Marketers only control brands up to the point of introduction, then brands are altered through the process of co-creation once they are introduced to the market and social system in which they operate (Ligas and Cotte, 1999).

Co-creation is related to service-dominant logic, which provides a theoretical approach for consumer-centric marketing. Service-dominant logic is now considered a continuous learning process in which the firm develops core competences, identifies potential consumers, cultivates relationships through customised value propositions and interprets marketplace feedback (Vargo and Lush, 2004; Tynan et al., 2010). The concept of cocreation is broader than consumer value creation (Ind and Coates, 2013) and can be categorised into various forms, including co-production, co-design (Sanders and Stappers, 2008), among others (Frow et al., 2011). While much of the marketing literature on cocreation focuses on the consumer's interaction with the brand (Atwal and Williams, 2009; Payne et al., 2008; Payne et al., 2009), the influence of stakeholders is beginning to be recognised (Hatch and Schultz, 2010; Helm and Jones, 2010; Frow et al., 2011; Frow et al., 2015).

In contrast to the emphasis on consumer perception and engagement, de Chernatony (2001) makes the argument for an internal focus on the organisation due to the significance of brand identity and the way in which managers create unique brands. The conceptual view of the firm in regard to its culture and vision guides decision-making for relationships, brand personality and product positioning (de Chernatony, 1999; Hatch and Schultz, 2010). From an organisational perspective, brand development is achieved through symbolic interaction 
between the enterprise and consumers (Urde, 1999). These two perspectives illustrate the gap between theory and practice of brand development from the organisational perspective and the consumer-centred approach (da Silveira et al., 2011; Urde, 2013).

Additionally, overwhelming focus on the influence of end users in the co-creation of brands, ignores the systems in which firms operate (Frow and Payne, 2011). Products are the interface within a broader social system that connects consumers to organisations (Solomon, 1983). Within the fashion industry, DFEs are tied not only to consumers, but neighbouring brands, collaborators, seasonal fashion schedules and industry-led supply chain processes. The global fashion system is a dynamic set of individuals and environments which collectively exert power over the DFE's opportunities, activities and survival (Power and Hauge, 2008). This research examines co-creation as the interactions with stakeholders that cumulatively produce new knowledge and meaning (co-meaning creation) over time (Frow et al., 2011).

\section{Designer Fashion Enterprises}

Previous research related to brand development of DFEs primarily examines the evolution of business models, brand strategies and the challenges of global brand image inconsistencies of large established firms (Moore and Birtwistle, 2004; Matthiesen and Phau, 2010; Moore and Doyle, 2010), with limited research on co-creation (Kang, 2014; Roser et al., 2014). This research explores entrepreneurial DFEs, characterised as non-established new entrants to the fashion industry. Entrepreneurial DFEs are defined as fashion design firms that produce products within the upper market segments between designer luxury and contemporary price-points, and are in the earliest stages of development (typically in operation less than 10 years).

SME designer fashion enterprises have been identified as key sectors of economic growth within the fashion industry (British Fashion Council, 2012). Throughout their development, they form unique and dynamic networks to support their economic sustainability. These networks permeate all levels of the supply chain as DFEs develop influential relationships, collaborations and partnerships with textile suppliers, manufacturers, sales and PR agencies, and retailers throughout the global fashion system (Karra, 2008). The previous two decades has seen increasing focus in the media on DFEs, with the introduction of various formal support initiatives in partnership with the British Fashion Council and Council of Fashion Designers of America, such as NewGen, International Woolmark Prize and the Vogue Fashion Funds. These firms are characterised as 'emerging designers' within the fashion media, and are recognised for their innovative contributions to the market (Malem, 2008).

Despite their recognised importance to their national economies and industries, and the increasing attention within the news media, little academic research exists on the development of these entrepreneurial firms. Rantisi (2002) defines them as manufacturers who possess only the design and marketing functions in-house, while production is an outsourced process. The in-house core-competencies for fashion design firms are those that surround product design, such as the selection of textiles, silhouettes and aesthetics of garments (Cholachatpinyo et al., 2002; Caniato et al., 2013). However, the point of differentiation for these firms is not only their products, manufacturing management or distribution processes, but the unique brand identity that results from the designer's innovative approach to the intangible characteristics of the collections (Malem, 2008). The aesthetic approach to brand positioning creates the brand's exclusivity within the market (Power and Hauge, 2008). This aesthetic innovation is born from the designer-founder's personal background, emphasis on creativity, approach to the business management of the enterprise and understanding of brand equity within the market (Malem, 2008). 
Brand equity and the perceived value of products, developed through the process of co-creation, creates the justification for the premium price associated with luxury goods positioned within the highest product category segments (Keller, 2008; Tynan et al., 2010). Kunz (1995) identifies the target market as the central focus of the organisation, reflecting the perceived management style and role of merchandising within apparel firms. However, the designer sector of the fashion industry is dominated by micro business, which operate with less than 10 employees (Malem, 2008). In practice, the ability and extent to which these entrepreneurial firms can principally and accurately focus on their target market is slight given their extremely limited resources. The development of the entrepreneurial designer fashion brand can be explained through the process of co-creation within the context of the fashion system, which has yet to be explored in the literature.

\section{Methodology}

This study utilised grounded theory to explore the brand and internationalisation strategies of SME womenswear design firms with studios based in London and New York. The use of grounded theory was incorporated to develop theoretical understanding within the substantive area of the marketing and management practices of DFEs (Glaser and Strauss, 1967; Strauss and Corbin, 1998). As a methodological approach, grounded theory offered the framework to examine the contemporary phenomenon of the entrepreneurial development of emerging design firms - an area that is otherwise lacking in previous research. The research design was exploratory in nature and sought to explain the relationship among identified variables which emerged from data gathering and analysis.

The purpose of this study is to theoretically explain how entrepreneurial SME womenswear DFEs develop their brands during the course of internationalisation. The concept of co-creation emerged as a category of the theoretical model explaining the development of the SME designer brand in the global fashion marketplace. Grounded theory has previously been used in management research because of its ability to capture the complexity of activities, processes and interactions, flexibly fit to the practice under investigation, and offer a theoretical explanation within new areas of the field (Locke, 2003). The purpose of grounded theory is to develop a theory derived from the 'basic social process', or practice, of the research participants (Glaser and Strauss, 1967). It utilises a series of methods incorporated into the research process in an iterative approach (Suddaby, 2006; Birks and Mills, 2011)

This research project used semi-structured in-depth interviews, observation at New York, London and Paris Fashion Weeks, and analysis of websites, social media and press. Due to the nature of the fashion industry schedule, data gathering was divided into 'phases' which immediately followed the presentation of designer collections at fashion week. This worked to improve the potentiality of including as many participants as possible by connecting with designers before they were involved in the creation of the next season's collections. Sources of data were chosen using a process of theoretical sensitivity to follow leads as they emerged within the research working to a point of theoretical saturation (Strauss and Corbin, 1998).

The participants of the study were purposively chosen from a database of womenswear DFEs who launched collections between 2005 and 2014, with studios based in London or New York. The ten year age range of the firm indicates the entrepreneurial birth of the brand and provided for a range of diversity of firms along the developmental process towards business maturity and economic sustainability. This is supported by previous research which determined that DFEs require an average of eight years to reach maturity and establish within the industry (Karra, 2008). A database of womenswear designers was created using websites relating to both London and New York fashion weeks, and the British Fashion 
Council's and Council of Fashion Designers of America's Vogue Fashion Funds. This database was used for the recruitment of participants and online data gathering in Phase IV. Due to the diverse nature of the businesses, while all the participants were required to produce a womenswear collection, many also produced products in other categories including menswear and accessories, among others. The participants also produced among a range of price-points including contemporary, advanced contemporary, entry-designer and designer luxury, often innovating within or defining new niche product segments. The brands distributed their products via one or more wholesale (department store, speciality boutique, online) or retail (flagship, e-commerce, private clients) channels.

The first phase of the research served as a pilot and included four interviews with three participants, two based in London and one in New York. This phase included a followup interview with the first designer from London, who was available to participate at the beginning and end of the data gathering period. The participants were asked to participate in a semi-structured in-depth interview lasting approximately one hour and to complete a brief survey which gathered demographic data about the individual and company for classification purposes. The interviews were conversational in nature and explored the participants' experiences, activities and processes in developing their products and company (Table 1). The interviews were transcribed and coded using Atlas.ti data analysis software. All identifying information was removed from the transcriptions. Anonymity allowed the participants to openly discuss sensitive business information without adding limitations to the research results. This was achieved because the objective of the research was to determine the process of developing the designer fashion brand, not the identifiable description of the individual brands themselves. After coding and categorisation, the data was analysed to reach a point of generalisation around the underlying shared basic social process among the participants. Open coding included line-by-line and in-vivo codes which worked to highlight keywords and themes. Each of the individual incidents were compared to each other, followed by categorisation using constant comparative analysis.

The second phase of research included 10 interviews with New York participants and seven interviews in London. Each of the participants completed a demographic data survey and were asked a series of questions that were refined based on the data collection during the first phase. Again, these interviews were transcribed and open-coded. Axial and selective coding developed through several periods of expansion and contraction as new ideas emerged and codes were refined into categories (Strauss and Corbin, 1998). Memo writing was incorporated after each interview, during transcription and during analysis, to provide further direction for the research, refine codes and categories, and obtain theoretical saturation.

\section{TABLE 1 ABOUT HERE, PLEASE}

The third phase included eight interviews in New York and nine in London with new and repeat participants. The questions for this phase of semi-structured interviews were developed from the analysis of the first two phases. Additionally, this phase included an extended survey developed to verify categories from previous phases. This phase worked towards generalisation and theoretical integration of data. A total of 20 DFEs and four support organisations participated in the study. Nine designer fashion firms and two support organisations (sales and PR agencies) were based in New York, and 11 designer fashion firms and two support organisations were based in London. A total of 38 interviews were conducted. As an accompaniment, the fourth phase used readily available information online of 149 brands to categorise DFE's internationalisation rate based on stockists, PR and sales agent usage based on contact information, product categories, social media platform usage, 
price-points, number of collections produced per year, usage of e-commerce, and categories of press coverage.

Triangulation of concepts across companies of various sizes, ages, locations, and multiple data sources (interviews, surveys, observation, online) ensured validity and reliability of the results (Locke, 2003). Additionally, the iterative process of open, axial and selective coding, and the use of analysis software assisted in the creation of an 'audit trail', tracing emergent concepts back to incidents in the raw data (Strauss and Corbin, 1998).

\section{Findings \& Discussion}

The concept of co-creation emerged as a sub-category to the process of DFE brand development during internationalisation. It was observed as an interaction between the design aesthetic of the collections and the DFE's integration into the fashion system via fashion week participation, sales negotiations and editorial placement. Within fashion week showrooms and presentations, buyers, editors and other industry influencers provide feedback on designers' collections. The concept also emerged during interviews as participants continuously discussed the reception of the brand by industry stakeholders and their reactions and incorporation of feedback into product development adaptations and future decisionmaking. For the DFE, co-creation can be categorised as a process of presentation, interpretation and reaction which occurs as a result of product development and interaction within the fashion system (Figure 1).

\section{Presentation}

\section{FIGURE 1 ABOUT HERE, PLEASE}

The fashion industry revolves around a regimented schedule of product design, production and distribution scheduled by the presentation of the collection to press, buyers and (increasingly) consumers at fashion weeks in February and September. Prior to presentation is product development, which is significantly influenced by the designer's background and aesthetic. The combination of collection development activities and the designer's identity provides a foundation for the brand's unique point-of-view and differentiation within the industry. The presentation of the collection creates interaction surrounding the brand, as the DFE generates interest from press, buyers and other influential members of the industry, as evidenced by the following quote:

'The very beginning. The day. The first two weeks. We didn't know. We didn't have a plan. There was no plan. And then within two weeks we realised what stores were interested and what publications were interested, and we realised the level of brand that we were going to be.' - Brand 5, New York

Co-creation begins with presenting the 'capsule' collection to the designer's personal and professional networks as an entry point into the fashion system. The fashion system is the networked structure of the fashion industry and the 'machine' of influential decision-makers who may help or hinder a new entrant. The DFE interacts with their personal and professional network, the industry, consumer market and global forces (social, political and economic trends) (Figure 2). Each of the interactions contributes to the co-creation of the brand, but the influence of buyers and editors is extremely visible. It is at this point of interaction the DFE potentially cultivates relationships with key stockists and editors that shape opportunities for growth. For example, this participant explains,

'So the collection started as a capsule of shirts and shirt dresses. And then the buyer at Liberty saw it and championed it and bought it, and encouraged 
them [the owners] to build it up and make it a bit more of a collection. And at the same time, an editor from Vogue also came on the scene and said, 'oh this is interesting and this is really fresh'... So that's kind of where the brand came from.' - Brand 12, London.

\section{FIGURE 2 ABOUT HERE, PLEASE}

In addition to the designer's background, the collections, fashion industry and consumers were identified as potential sources of brand identity. However, the participants overwhelming recognised that the source of brand identity stems from the collections, not the industry, consumer or designer (Figure 3), highlighting the complexity of brand development for an entrepreneurial fashion business. Brand identity was considered to be discovered over time. Designers provide direction, the collections are a source of brand identity, and the 'signature' that defines the brand takes time to cultivate, as explained by the following participant:

'I was thinking of that first collection, [when buyers asked], "What's your signature," when we first started. And we were like, "We've only started. We don't have a signature yet." But that was a question that at the time a lot of people were asking ... But they don't create it. So, we can create it and they can go, have an opinion, but they don't direct it. The only thing that can direct it is what is in our heads' - Brand 19, London.

It is through the practice of continually producing collections and presenting them to the fashion system - seeking sales, press and consumers - that assists in the cultivation of brand identity. Collections are created in the context of the fashion system and the environment in which DFEs operate. The interaction of the DFE with buyers, editors and other stakeholders generates feedback. This feedback is interpreted by the DFE in the process of sales negotiations, sell-through analysis, product adaptations and future product development.

\section{FIGURE 3 ABOUT HERE, PLEASE}

\section{Interpretation}

Each interaction with stakeholders is a source of feedback, requests, demands, opinions, and impressions about the designer, garments, collections, and brand. This is a key source of learning and experience for the DFE as the firm negotiates its position and opportunities. Interactions generate a dialogue (Hatch and Schultz, 2010; Frow and Payne, 2011; Grönroos, 2011; Grönroos and Voima, 2011) as the firm and stakeholder interpret and analyse brand meaning in relation to their own experience, desires and goals. This is illustrated by buyers making specific requests for alterations in the length, colour or fabric of garments, or entirely new designs. For example,

'A buyer comes in and says, "You know what, we don't have this. Can you please fill that gap?" When you say, "But wait, this is me." You know what I mean? You have to really pick and choose.' - Brand 6, New York.

Buyers may request alterations for current season garments - such as the addition of sleeves - or additional garments to the collections for future seasons based on sell-through rates (the percentage of garments that sell through to the end consumer at full-price). At the 
end of distribution for each season's collections, this data is communicated back to the DFE, used as a source of learning about the end consumer and what garments they are purchasing. The following participant describes this process:

'We [the sales team] sit down and talk with [the designer]. You know, this is what the North American market is asking for. This is what the UK is asking for. This is what the Chinese are asking for. How do we find something in the middle? How do we satisfy this? Where do we want to go? Can you do more tops? Can you do less tops? So these are really big influences and you can see those coming through in the collection'. - Brand 4, New York.

However, feedback derived from the multiple sources and interactions DFEs experience can be conflicting, as when buyers within the same geographic market request different design directions, or when various regions expect different things from the brand. For brands in the earliest stages, data can be limited and contradictory, as evidenced by the quote from this participant:

'It's tough to do when, again, the sales is so spread between these stores. It's so tough. Because again, one person could love something and one person could feel differently about it. This I would say is the toughest part of my job. And I have to come in and make the decision about what to chop and what to keep, even though I'm using five different people's words that are completely the opposite of each other. This is what I struggle with, and the fact that I've had to drop some of the basic pieces that I loved.' - Brand 13, London.

The nature of these interactions demonstrate why co-creation is a process of negotiation in which the DFE interprets experiences based on their own goals. For the DFE, co-creation interactions are a continual source of learning to discover the brand identity (da Silveria et al., 2011; Urde, 2013). For instance,

'You have to identify brand attributes and things like that. And sometimes they'll tell you something different than to what other people think. We had a Harvey Nichols feature and they wrote a really good line that we really liked. ... It's matching what we're thinking.' - Brand 3, London.

The interpretation of co-creation experiences, such as buyer and editor feedback, present challenges and opportunities for the integration of the DFE into the fashion system as they seek sales and press. Positive or negative reaction to feedback through strategic decision making ultimately affects and allows the DFE to control the brand. The DFE's interpretation of feedback determines product development (Boyle, 2007).

\section{Reaction}

The DFE's reaction to co-creation can be positive or negative in which feedback is either accepted or rejected in the process of decision making. Misalignment of goals, resources and capabilities results in negative value creation or 'co-destruction' (Storbacka et al., 2012). It is the firm that ultimately controls the direction of the brand through the design of the collections. Relying too heavily on feedback may create a situation in which the DFE experiences a loss of direction. This creates challenges for the brands, as illustrated in the following quote: 
'I can't listen to all of these people anymore. There's no point. What happened was, in the course of one season it went from being an amazing thing, to having no personality. And as a young person, I got sucked into that, of people saying "This is what you should be doing". Bergdorf's is telling me I should be doing printed gowns, but it wasn't me. So there's no value it in.' - Brand 6, New York.

The reaction component of the co-creation process recognises that there is 'push back' against images or ideas that don't align with the designer's vision. For example, the following participant explains,

'And having someone else say what your brand should be to you is quite a lot like, '[shocked sound] Why can't it be this?! We want it to be this. And we're the brand, so we'll do it!' - Brand 12, London.

How the DFE navigates the process of integrating into the fashion system by developing relationships within the networked supply chain of suppliers, manufacturers, buyers and editors; positions the products according to aesthetics, quality and price-points; and embodies the meanings associated with being a British, American or international designer each work to co-create the brand. The images reflected onto the DFE present opportunities when they are in alignment with the brand's goals, and challenges when they are conflicting. Even images that are considered 'positive', such as being an 'emerging designer' which garners significant press, can constrain the brand in its growth efforts as it seeks to establish a sustainable position within the industry. Similarly, where the brand is from also influences its image, requiring the 'education' of stakeholders. For example,

'When you're considered not only emerging, but an American designer, it's hard to break into those other categories. But it's about training the customer right now, not to look at us ... as this American emerging. They don't realise that because you're American and you're emerging - so they think it's less expensive. But that's not going to work when you're trying to build a profitable business in other brand extensions.' - Brand 4, New York.

To establish a unique position within the market the DFE reacts to images by making strategic decisions, for example, rejecting editorial placements for 'emerging designers', cultivating relationships and co-creation experiences that reflect its desired identity. Within the global fashion system, how the DFE responds to individual interpretations of the brand allows the firm to maintain control. It is through the co-creation process that they are able to evolve and grow the business while remaining true to the brand identity. Many participants described the process of 'discovering' their identity, which was 'always there', clarified with experience. This is illustrated by the following participant:

'The core is still the same because it's [the designer's] sensibility. It's changed because being in the business on your own and having no net behind you, you have to be crafty enough to know that every time you do a collection you put everything into it. And you need to make sure you don't go overboard, otherwise you close. We've evolved in the sense that we know better our customers now. We know better how the machine works: delivery, production, how the press works, how people react. We are more lucid in the overall picture of how the business runs. In fashion, in our own personal business, 
who we're dressing, and what they're looking for when they come to see us.' Brand 8, New York.

Within the DFE, the designer is the storyteller and the brand reflects the story of the enterprise's identity, carrying the message of the core values underlying the organisation and its products (Salzer-Mörling and Strannegård, 2004; Urde, 2013). This in turn influences the relationships that the firm develops within the fashion industry, its market positioning, and the brand identity. The power of the brand in negotiating co-creation grows over time as aesthetic definitions collectively and consistently emerge in the dialogue surrounding the brand, providing strategic direction for management decision-making.

\section{FIGURE 4 ABOUT HERE, PLEASE}

Co-creation is a process of presenting ideas, interpreting experiences, and reacting to learning to discover the brand identity (Figure 4). The process of presentation-interpretationreaction allows the DFE to identify characteristics that provide its unique market position. Co-creation is a function of interaction (Grönroos and Voima, 2011), so that both the firm and stakeholder are educated about the brand from the experience. As companies become differentiated not by the tangible features of their products but the aesthetic qualities of their brands, marketing is no longer about the making and selling of product, or the customisation of services, but the exchange of meaning in a dialogue of interaction (Ind and Coates, 2013).

\section{Conclusions}

Co-creation is not a phenomenon in which the DFE gives up all control over the brand. Indeed, the brand identity would not exist if the designer did not initially introduce innovations to the market (Hatch and Schultz, 2010). This research examines the process of co-creation from the perspective of the DFE, exploring their reaction to co-creation in practice. Brand value is co-created not only through producer-consumer interaction, but with stakeholders (Helm and Jones, 2010). Additionally, the innovation and meaning connected to that value (Ind and Coates, 2013; Frow et al., 2015), the defining elements of the brand, begin and end with the firm who introduces them through the development of each collection. Brand identity is discovered through interaction with stakeholders in the fashion industry.

These findings answer a call for research on the impact of stakeholders on co-creation (Hatch and Schultz, 2010; Frow et al., 2011). This research examines the co-creation phenomenon from the perspective of the firm, exploring their interpretation and reaction to co-creation experiences. This research highlights the interplay between co-creation of meaning and brand identity, recognising that there is not an either/or approach to marketing but a complex interaction and dialogue (Helm and Jones, 2010; da Silveira et al., 2011; Frow et al., 2015). This brand-oriented perspective incorporates the design innovations created and presented by the organisation during the collection (product) development process. This extension of co-creation recognises how DFEs develop products and learn about stakeholders through fashion industry integration. The successful DFE rejects stakeholder feedback that falls beyond the scope of the brand, while seeking out co-creation experiences that reflect its vision.

\section{Managerial Implications}

For the DFE, a clear point-of-view is path dependent (Urde, 2013) based on the designer's background, identity and design aesthetic. The designer's background creates a launch point for the brand story, creating confidence as a result of a clear vision. Designer fashion enterprises should seek interactions that increases learning about buyers, editors and 
consumers. The incorporation of feedback should be in line with the desired brand identity and goals of the firm. Management of the co-creation process requires a balance between the service of stakeholder needs and the firm's vision, merging short-term market response with long-term brand building (Helm and Jones, 2010). Interactions with stakeholders should be a social negotiation in which the DFE gathers information, support and resources, while educating individuals about its goals, aesthetic and unique point-of-view. Co-creation is a process of reciprocal discovery in which a common shared dialogue of meaning surrounding the brand is created through interaction.

\section{Limitations and Future Research}

This was an exploratory study that examined a niche segment of the global fashion industry, focusing on the entrepreneurial development of DFEs in the most exclusive pricepoints within London and New York. Further research is required to generalise the findings to other segments of the industry, and to other geographic locations. Additionally, this paper discusses one component of co-creation (co-meaning creation) in relation to buyers and editors as stakeholders, further research on the typology of co-creation within the fashion industry is required.

\section{References}

Atwal, G. and Williams, A. (2009), "Luxury brand marketing-The experience is everything!" Journal of Brand Management, Vol. 16 No. 5, pp. 338-346.

Birks, M. and Mills, J. (2011), Grounded Theory: A Practical Guide, London: Sage.

Boyle, E. (2007), "A process model for brand cocreation: brand management and research implications", Journal of Product \& Brand Management, Vol. 16 No. 2, pp. 122-131.

British Fashion Council (2012), "Future of Fashion: Strategic Considerations for Growth", available at: http:// www.britishfashioncouncil.com/content/1890/Future-of-Fashion (accessed: 29 December 2012).

Caniato, F., Caridi, M. and Moretto, A. (2013), "Dynamic capabilities for fashion-luxury supply chain innovation", International Journal of Retail and Distribution Management, Vol. 41 No. 11/12, pp. 940-960.

Cholachatpinyo, A., Fletcher, B., Padgett, I. and Crocker, M. (2002), “A conceptual model of the fashion process-part 1: The fashion transformation process model", Journal of Fashion Marketing and Management, Vol. 6 No. 1, pp.11-23.

Choo, H. J., Moon, H., Kim, H. and Yoon, N. (2012), "Luxury customer value", Journal of Fashion Marketing and Management, Vol. 16 No. 1, pp. 81-101.

da Silveira, C., Lages, C. and Simões, C. (2011), "Reconceptualizing brand identity in a dynamic environment", Journal of Business Research, Vol. 66, pp. 28-36.

de Chernatony, L. (2001), "A model for strategically building brands", Journal of Brand Management, Vol. 9, pp. 32-44.

de Chernatony, L. (1999), "Brand Management through narrowing the gap between brand identity and brand reputation", Journal of Marketing Management, Vol. 15 No. 1-3, pp. 157-179.

Fernie, J., Moore, C.M. and Lawrie, A. (1998), "A tale of two cities: an examination of fashion designer retailing within London and New York", Journal of Product and Brand Management, Vol. 7 No. 5, pp. 366-378.

Fionda, A.M. and Moore, C.M. (2009), "The anatomy of the luxury fashion brand", Journal of Brand Management, Vol. 16 No. 5, pp. 347-363. 
Frow, P., Nenonen, S., Payne, A. and Storbacka, K. (2015), "Managing co-creation design: A strategic approach to innovation", British Journal of Management, Vol. 26 No. 3, pp. 463483.

Frow, P. and Payne, A. (2011), "A stakeholder perspective of the value proposition concept", European Journal of Marketing, Vol. 45 No. 1/2, pp. 223-240.

Frow, P., Payne, A. and Storbacka, K. (2011), “Co-creation: A typology and conceptual framework", in Proceedings of ANZMAC, pp. 1-6.

Glaser, B.G. and Strauss, A.L. (1967), The Discovery of Grounded Theory (Kindle Edition 2009). New Brunswick (USA) \& London (U.K.): Aldine Transaction.

Goworek, H. (2010), “An investigation into product development processes for U.K. fashion retailers: A multiple case study", Journal of Fashion Marketing and Management, Vol. 14 No. 4, pp. 648-662.

Grönroos, C. (2008), “Service logic revisited: who creates value? And who co-creates?", European Business Review, Vol. 20 No. 4, pp. 298-314.

Grönroos, C. (2011), "Value co-creation in service logic: A critical analysis", Marketing Theory, Vol. 11 No. 3, pp. 279-301.

Grönroos, C. and Voima, P. (2011), "Making sense of value and value co-creation in service logic", working paper no. 559, Hanken School of Economics, Helsinki, Finland.

Guercini, S. (2001), "Relation between branding and growth of the firm in new quick fashion formulas: analysis of an Italian case", Journal of Fashion Marketing and Management, Vol. 5 No. 1, pp. 69-79.

Hatch, M.J. and Schultz, M. (2010), "Toward a theory of brand co-creation with implications for brand governance", Brand Management, Vol. 17 No. 8, pp. 590-604.

Helm, C. and Jones, R. (2010), "Extending the value chain - A conceptual framework for managing the governance of co-created brand equity", Brand Management, Vol. 17 No. 8, pp. 579-589.

Ind, N. and Coates, N. (2013), "The meanings of co-creation", European Business Review, Vol. 25 No. 1, pp. 86-95.

Kang, J.-Y.M. (2014), "Repurchase loyalty for customer social co-creation e-marketplaces", Journal of Fashion Marketing and Management, Vol. 18 No. 4, pp. 452-465.

Karra, N. (2008), The U.K. Designer Fashion Economy - Value relationships- identifying barriers and creating opportunities for business growth. A report commissioned for the Centre for Fashion Enterprise and Nesta, available at: http://www.fashionenterprise.com/wp-content/ files/2013/03/UK-Designer-Fashion-Economy-ReportDecember-2008.pdf (accessed: 3 November 2013).

Keller, K.L.(2008), Strategic Brand Management: building, measuring and managing brand equity, 3rd Edition, Prentice-Hall, Upper Saddle river, NJ.

Kunz, G.I. (1995), "Behavioural theory of the apparel firm: A beginning”, Clothing and Textiles Research Journal, Vol. 13 No. 4, pp. 252-261.

Ligas, M. and Cotte, J. (1999), "The process of negotiating brand meaning: A Symbolic interactionist perspective", Advances in Consumer Research, Vol. 26, pp. 609-614.

Locke, K. (2003), Grounded Theory in Management Research, London: Sage.

Lusch, R.F. and Vargo, S.L. (2006), "Service-dominant logic: Reactions, reflections and refinements", Marketing Theory, Vol. 6 No. 3, pp. 281-288.

Malem, W. (2008), "Fashion designers as business: London”, Journal of Fashion Marketing and Management, Vol. 12 No. 3, pp. 398-414. 
Matthiesen, I. and Phau, I. (2010), "Brand image inconsistencies of luxury fashion brands: A buyer-seller exchange situation model of Hugo Boss Australia", Journal of Fashion Marketing and Management, Vol. 14 No. 2, pp. 202-218.

McColl, J. and Moore, C. (2011), "An Exploration of fashion retailer own brand strategies", Journal of Fashion Marketing and Management, Vol. 15 No. 1, pp. 91-107.

Merz, M.A., He, Y., and Vargo, S.L. (2009), "The evolving brand logic: a service-dominant logic perspective", Journal of the Academy of Marketing Science, Vol. 31 No. 3, pp. 328344.

Moore, C.M. and Birtwistle, G. (2004), "The Burberry business model: creating an international luxury fashion brand", International Journal of Retail and Distribution Management, Vol. 32 No. 8, pp. 412-422.

Moore, C.M. and Doyle, S.A. (2010), "The evolution of a luxury brand. The case of Prada", International Journal of Retail and Distribution Management, Vol. 38 No. 11, pp. 915927.

Payne, A., Storbacka, K., Frow, P. and Knox, S. (2009), "Co-creating brands: Diagnosing and designing the relationship experience", Journal of Business Research, Vol. 62, pp. 379389.

Payne, A., Storbacka, K. and Frow, P. (2008), "Managing the co-creation of value", Journal of the Academy of Marketing Science, Vol. 36, pp. 83-96.

Power, D. and Hauge, A. (2008), "No man's brand--brands, institutions, and fashion", Growth and Change, Vol. 39 No. 1, pp. 123-143.

Prahalad, C.K. and Ramaswamy, V. (2004), "Co-creation experiences: The next practice in value creation", Journal of Interactive Marketing, Vol. 18 No. 3, pp. 5-14.

Rantisi, N.M. (2002), "The competitive foundations of localised learning and innovation: The case of women's garment production in New York City", Economic Geography, Vol. 78 No. 4, pp. 441-462.

Roser, T., DeFilllippi, R. and Cooke, J.G. (2014), "Co-creation in design: how the UK company Own Label combines openness and ownership to manage talent", Strategy \& Leadership, Vol. 45 No. 5, pp. 34-40.

Salzer-Mörling, M. and Strannegård, L. (2004), "Silence of the brands", European Journal of Marketing, Vol.38 No.1/2, pp. 224-238.

Sanders, E. B.-N. and Stappers, P. J. (2008), "Co-creation and the new landscapes of design", CoDesign: International Journal of CoCreation in Design and the Arts, Vol. 4 No. 1, pp. 5-18.

Solomon, M.R. (1983), "The role of products as social stimuli: A symbolic interactionism perspective", Journal of Consumer Research, Vol. 10, pp. 319-329.

Storbacka, K., Frow, P., Nenonen, S. and Payne, A. (2012), "Designing business models for value co-creation", in Vargo, S.L. and Lusch, R.F. (Ed.), Special Issue - Toward a better understand of markets and marketing (Review of Marketing Research, Volume 9), Emerald Group Publishing Limited, pp. 51-78.

Strauss, A. and Corbin, J.M. (1998), Basics of Qualitative Research: Techniques and Procedures for Developing Grounded Theory. 2nd Ed. London: Sage Publications.

Suddaby, R. (2006), "From the editors: What grounded theory is not", Academy of Management Journal, Vol. 49 No. 4, pp. 633-642.

Tynan, C., McKechnie, S. and Chhuon, C. (2010), "Co-creating value for luxury brands", Journal of Business Research, Vol. 63, pp. 1156-1163. 
Urde, M. (1999), "Brand orientation: A mindset for building brands into strategic resources" Journal of Marketing Management, Vol. 15 No. 1-3, pp. 117-133.

Urde, M. (2013), "The corporate brand identity matrix", Journal of Brand Management, Vol. 20 No.9, pp. 742- 761.

Vargo, S.L. and Lusch, R.F. (2004), "Evolving to a new dominant logic for marketing", Journal of Marketing, Vol. 68, pp. 1-17.

Wigley, S.M. and Moore, C.M. (2007), "The operationalisation of international fashion retailer success." Journal of Fashion Marketing and Management, Vol. 11 No. 2, pp. 281296. 


\section{Table 1: Interview Questions}

Phase I: These questions were a launching point for the conversation. Follow up questions were used throughout the interview to explore concepts introduced by the participants.

- Tell me the story of how the company was started.

- How would you describe the company's identity or story? How has it evolved?

- How do you share the story? What methods do you use?

- What is it about this brand that no one else is doing? What makes it unique?

- Tell me about the collection lifecycle.

- Tell me about the sales and distribution process - what is that like? Do you source internationally or sell internationally?

- What is the ultimate vision or goal for this company? 


\section{Table 1: Interview Questions}

Phase II: For new participants, some of the Phase I questions were used as well. Not all of these questions were used in every interview, depending on time and the discussion that took place.

- Is there any news that you'd like to share? (for repeat participants)

- What are the major milestones that the company has evolved through?

- What are some of the things that you've done to help your company to grow and develop? What's worked? What hasn't? Why?

- What are the things that make you able to grow?

- How do you know when you're ready to take the next step?

- Have you ever been in a position where you felt like the company's development or growth was out of control? When? What was it like?

- Are you a brand? At what point did the label become a 'brand?'

- What is it about this brand that no one else is doing? What makes it unique?

- Do you want the brand to be consistently viewed as representative of particular elements? How do you control that when distribution is so diverse?

- What's your next major step in the development of your company? Immediate \& long-term goals? What resources do you need to achieve them?

- What do the collections \& individual garments say about the designer? What do you want them to say? How does it change/evolve? What stays the same?

- Social Media: Why is it so important? What do you use it for? What do you say? How do you say it? Is there a connection between social media consumers and financial success? Or is it just a form of PR/awareness or editorial success? Is it a community of people interacting with each other or do they just interact with the brand?

- The fashion community is often viewed as very 'cut-throat' but it's also so collaborative. What makes this brand 'good enough' to be a part of the community?

- How important are the relationships that the company develops with collaborators? Can you give me an example of when a relationship made a big difference?

- What are some of the stages of growth the company goes through?

- What is a branding strategy? What are some of the branding strategies that you incorporate in your business? 


\section{Table 1: Interview Questions}

Phase III: For new participants, some of the Phase I \& Phase II questions were used as well. Not all of these questions were used in every interview, depending on time and the discussion that took place.

\section{Primary Questions:}

- How does the company's identity impact the strategies and decision making processes of the firm?

- How important is it to be defined by where you create the product or where it's produced? To what extant does that influence and impact the identity of the company?

- To what extent are the buyers, editors, industry, and network influential in defining what the brand is? And ultimately opening up or limiting access to consumers?

- How important it is to have a girl/woman? Does the girl/woman describe the consumer or muse or both? or Reflect the brand?

- Is being commercial, wearable, desirable in opposition to being creative / conceptual / editorial worthy?

\section{Secondary Questions:}

- At what point did the identity of the company begin to solidify? Did anything change at that point? Such as the approach to thinking about the company?

- How important are imagery and visuals for communicating?

- When you mention a brand that you admire to what extent does their business model or aesthetic influence the decisions you make?

- What's a better strategy focusing on creating great product or creating an image in the industry and market? Should you focus on sales or PR? One more than the other or both equally?

- When is it a good idea to expand into other product categories?

- How would you describe the approach to decision making? Has it changed over time?

Support Agent: Sales, PR, Showroom: These questions were a launching point for the conversation. Follow up questions were used throughout the interview to explore concepts introduced by the participants.

- How and why started your company?

- How many clients do you have?

- How would you describe the growth of your company?

- What are your goals?

- What makes you unique?

- Do you support designers branding and growth efforts? How?

- When you're bringing on a new designer \& discussing your plan with them, what are those conversations like? Do you notice things about their brand that maybe they don't notice? Do you point it out to them?

- Do you notice things about their growth and distribution that maybe they don't notice? Do you point it out to them?

- Most important part of your job? 


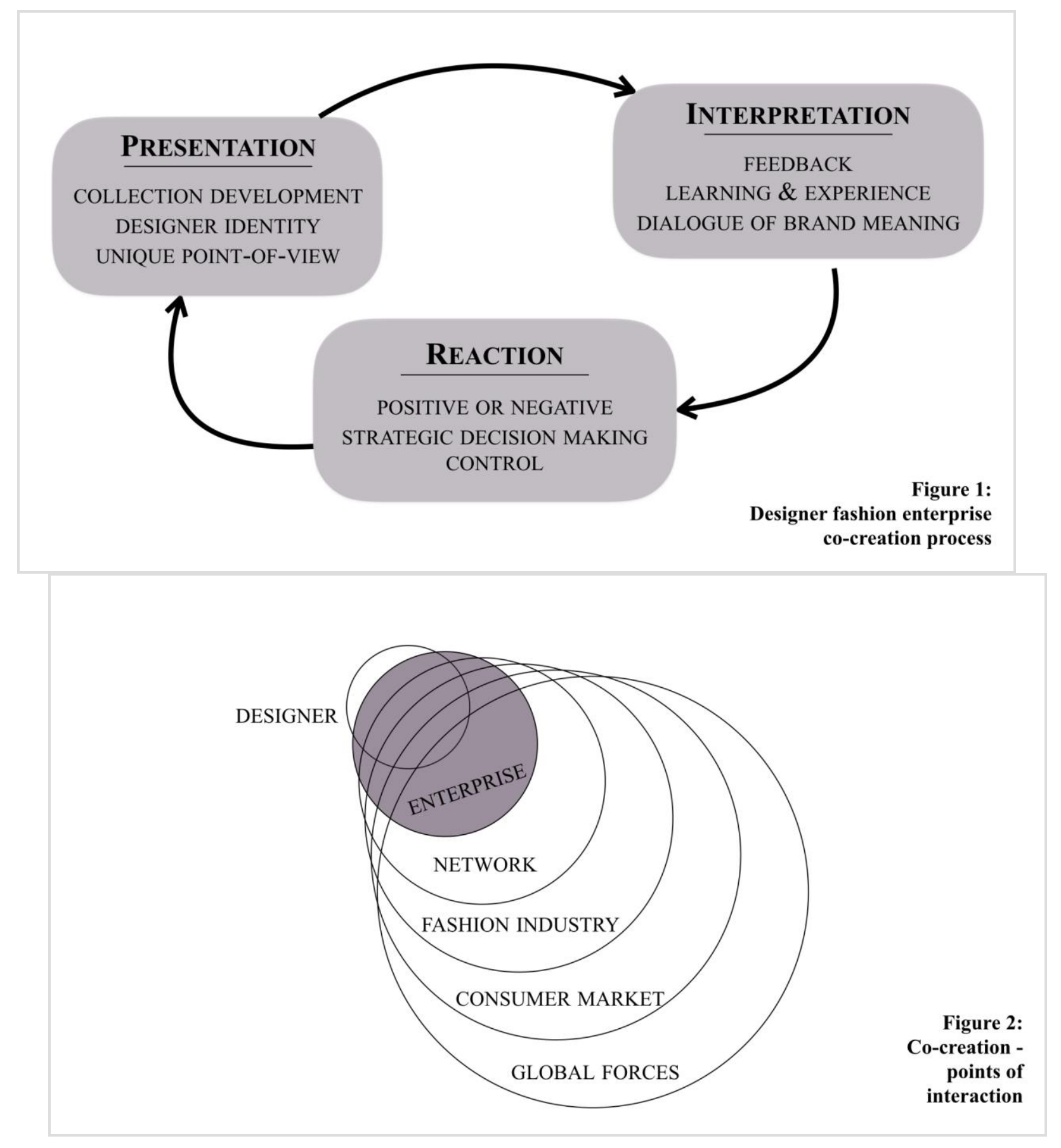



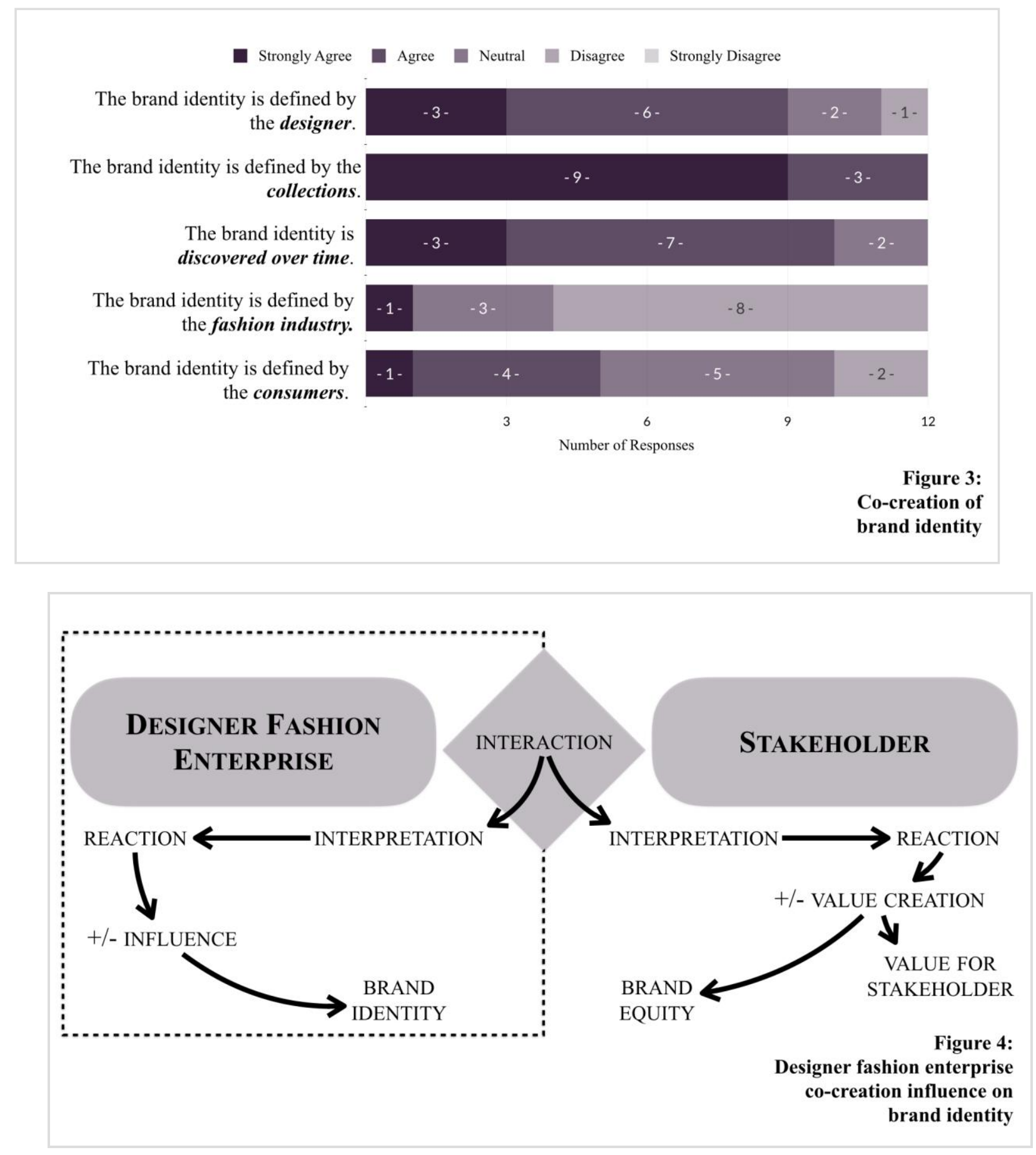